\title{
Kontakty skazanych ze światem zewnętrznym jako element procesu społecznej readaptacji
}

\begin{abstract}
Among the topics that Agata Hulak discusses in this article are: the modern methods of communication between convicts and their loved ones, the issue of so-called intimate visits, the issue of convicts' contacts with the outside world during the COVID-19 pandemic, and the results of the operations of supervising institutions.
\end{abstract}

Keywords: right to contacts, intimate visits, temporarily arrested, European prison regulations, ECtHR rulings, COVID-19

\section{Wprowadzenie}

Utrzymywanie kontaktu ze światem zewnętrznym w okresie przebywania w zakładzie karnym pozytywnie wpływa na proces resocjalizacji oraz ułatwia readaptację po zakończeniu odbywania kary. Katalog praw skazanych, obejmujący m.in. prawo do utrzymywania kontaktu ze światem zewnętrznym, prawo do informacji, prawo do edukacji, pracy, uczestnictwa w zajęciach kulturalno-oświatowych i sportowych, umożliwia osadzonym podążanie za niezwykle szybkim tempem zmian zachodzących w społeczeństwie.

Odnosząc się do terminu „proces społecznej readaptacji”, w ślad za Grażyną B. Szczygieł, należy wskazać na dwa ujęcia definicyjne. Pierwsze ujęcie prezentuje zbliżone rozumienie tego terminu do pojęcia resocjalizacji, gdyż odnosi się do „procesu społecznej readaptacji jako powrotu do społeczeństwa", który charakteryzuje się nie tylko powstrzymaniem się od popełniania przestępstw, ale także prawidłowym funkcjonowaniem w społeczeństwie, czyli w rodzinie, sąsiedztwie, pracy czy też grupie rówieśniczej. W drugim ujęciu natomiast, proces społecznej adaptacji jest 
rozumiany jako proces nauczania skazanych pełnienia ról społecznych, a także korzystania z przysługujących im praw oraz zaspokajania życiowych potrzeb przy jednoczesnym respektowaniu praw drugiego człowieka. Wskazane nauczanie rozpoczyna się w jednostce penitencjarnej i odbywa się przy wsparciu podmiotów oferujących skazanym pomoc w powrocie do życia po odbyciu kary pozbawienia wolności. Efekt tych działań powinien obejmować chęć przestrzegania norm społecznie obowiązujących w każdej dziedzinie życia w warunkach wolnościowych ${ }^{1}$.

Wskazać należy, że oba terminy - „resocjalizacja” i „społeczna readaptacji skazanych" - zostały użyte przez ustawodawcę w treści Ustawy z dnia 6 czerwca 1997 r. Kodeks karny wykonawczy. Termin „resocjalizacja” występuje w odniesieniu do skazanych odbywających karę pozbawienia wolności, natomiast „społeczna readaptacja skazanych” dotyczy regulacji obejmujących czas po opuszczeniu zakładu karnego przez skazanego $^{2}$.

W konsekwencji, oprócz podejmowania działań w ramach realizacji uprawnień z katalogu wskazanego w art. 102 k.k.w., zwraca się uwagę na wszelkie inne rozwiązania łączące się z procesem społecznej readaptacji, gdyż mają na celu minimalizację zjawiska niekorzystnego wpływu środowiska jednostek penitencjarnych na osadzonych w nich przebywających ${ }^{3}$.

Istotne jest to, że przeprowadzanie oddziaływań resocjalizacyjnych skazanych wiąże się z urozmaiconymi metodami readaptacji społecznej, do których zalicza się m.in. nauczanie, pracę, uczestnictwo w zajęciach kulturalno-oświatowych i sportowych, a także utrzymywaniem kontaktów ze światem zewnętrznym, w tym z rodziną. Katalog przedmiotowych oddziaływań jest zróżnicowany, ma charakter otwarty, gdyż ustawodawca $\mathrm{w}$ treści art. $67 \S 3$ k.k.w. nieenumeratywnie określił środki i metody oddziaływania penitencjarnego ${ }^{4}$.

${ }^{1}$ G.B. SzCZYGIEE: Społeczna readaptacja skazanych $w$ polskim systemie penitencjarnym. Białystok 2002, s. 11-12.

2 Ibidem, s. 11; Ustawa z dnia 6 czerwca 1997 r. Kodeks karny wykonawczy. Dz.U. $1997 \mathrm{nr} 90$ poz. 557 z późn. zm.

${ }^{3}$ K. LINowsKi: Możliwości rozwoju człowieka $w$ warunkach izolacji penitencjarnej poprzez utrzymywanie kontaktów zewnętrznych. „Acta Scientifica Academiae Ostroviensis” 2011, nr 8, s. 125. http://bazhum.muzhp.pl/media//files/Acta_Scientifica_Academiae_ Ostroviensis/Acta_Scientifica_Academiae_Ostroviensis-r2001-t-n8/Acta_Scientifica_ Academiae_Ostroviensis-r2001-t-n8-s125-143/Acta_Scientifica_Academiae_Ostroviensisr2001-t-n8-s125-143.pdf [dostęp: 2.02.2021].

${ }^{4}$ R. DeKA: Readaptacja społeczna skazanych jako jeden z warunków bezpieczeństwa społeczności lokalnych. W: Wielowymiarowość profilaktyki, resocjalizacji i readaptacji społecznej. Tradycja, współczesność i perspektywy inicjatyw probacyjnych. Red. P. FrącKOWIaK, M. SzYKUT. Toruń 2017, s. 137; W. FrIEDRICH: Wychowawczo-resocjalizacyjne środki oddziatywania na skazanych. „Ogrody Nauk i Sztuk” 2016, t. 6, s. 278. 
Dokonując analizy zagadnienia wpływu realizacji prawa skazanych do kontaktu ze światem zewnętrznym na proces społecznej readaptacji, należy zaznaczyć, że stanowi ona jedno z zasadniczych działań ograniczających negatywny wpływ izolacji, na który mogą się składać m.in. zaburzenia emocjonalne, nerwice, zaburzenia w sferze seksualnej czy nawet choroby psychiczne ${ }^{5}$. Utrzymywanie kontaktu przez skazanych z ich rodzinami oraz osobami bliskimi, podtrzymywanie więzi z nimi, ma zatem niezwykle istotne znaczenie dla poprawnego przebiegu procesu resocjalizacji penitencjarnej oraz jej końcowego efektu'

\section{Problematyka prawa skazanych do kontaktów ze światem zewnętrznym w systemie prawa polskiego i europejskiego}

Zgodnie z regulacją zawartą w art. 4 § 2 k.k.w. skazani, pomimo odbywania kary pozbawienia wolności, a $\mathrm{w}$ konsekwencji przebywania $\mathrm{w}$ warunkach izolacji, zachowują gwarantowane konstytucyjnie prawa i wolności obywatelskie. Ograniczenie tychże praw i wolności może mieć źródło jedynie $\mathrm{w}$ ustawie czy też $\mathrm{w}$ wydanym na jej podstawie prawomocnym orzeczeniu. Unormowania z zakresu poszanowania godności osób pozbawionych wolności można odnaleźć w wielu aktach prawa międzynarodowego, w tym w art. 10 ust. 1 Międzynarodowego Paktu Praw Obywatelskich i Politycznych, zgodnie z którym każda osoba pozbawiona wolności będzie traktowana $\mathrm{w}$ sposób humanitarny i z poszanowaniem przyrodzonej godności człowieka ${ }^{7}$.

Nieodzownym elementem inkanceracji jest izolacja od najbliższych, zmiana środowiska życia codziennego. Ustawodawca w treści art. 41 $\S 1$ k.k.w., w celu ułatwienia społecznej readaptacji, a w szczególności przeciwdziałania powrotowi do przestępstwa, wskazuje, że powinno się udzielać skazanym oraz ich rodzinom niezbędnej pomocy; pomoc ta nie została ściśle określona, wskazano jedynie główne formy wsparcia. Szczególną uwagę należałoby zwrócić na wszelkie formy wsparcia ska-

${ }^{5}$ K. LinowsKi: Możliwości rozwoju człowieka...

${ }^{6}$ H. MACHEL: Rodzina skazanego jako wspótuczestnik jego resocjalizacji penitencjarnej, readaptacji i reintegracji społecznej. „Resocjalizacja Polska” 2014, nr 7, s. 45. http://bazhum. muzhp.pl/media//files/Resocjalizacja_Polska_(Polish_Journal_of_Social_Rehabilitation)/ Resocjalizacja_Polska_(Polish_Journal_of_Social_Rehabilitation)-r2014-t7/ Resocjalizacja_Polska_(Polish_Journal_of_Social_Rehabilitation)-r2014-t7-s45-57/ Resocjalizacja_Polska_(Polish_Journal_of_Social_Rehabilitation)-r2014-t7-s45-57.pdf [dostęp: 2.02.2021].

7 Międzynarodowy Pakt Praw Obywatelskich i Politycznych otwarty do podpisu w Nowym Jorku dnia 19 grudnia 1966 r. Dz.U. 1977 nr 38 poz. 167. 
zanego w utrzymaniu kontaktów z rodziną, osobami najbliższymi, gdyż kara pozbawienia wolności niejednokrotnie wiąże się nie tylko z przerwaniem normalnych kontaktów rodzinnych w trakcie odbywania kary, ale także z potencjalnym brakiem wsparcia przez rodzinę lub bliskich po opuszczeniu jednostki penitencjarnej przez skazanego.

Wśród problemów związanych ze społeczną readaptacją skazanych na etapie zakończenia odbywania kary pozbawienia wolności wymienia się właśnie m.in. brak wsparcia ze strony rodziny lub bliskich, pozostawanie przez dozorowanego w konflikcie $\mathrm{z}$ rodziną ${ }^{8}$.

Należy zatem wskazać, że kontakty skazanych ze światem zewnętrznym, zwłaszcza $\mathrm{w}$ postaci kontaktów z najbliższymi, stanowią element wsparcia w procesie społecznej readaptacji. Mogą one przybierać różne formy, które dzielone są na dwie zasadnicze grupy, tj. kontakty bezpośrednie oraz kontakty pośrednie. Do kontaktów bezpośrednich należy zaliczyć wizyty najbliższych na terenie jednostki penitencjarnej, a także odbywające się, na rozmaitych zasadach, czasowe opuszczenie przez skazanego takiej jednostki. Wśród kontaktów o charakterze pośrednim wymienia się korespondencję, przekazywanie paczek, kontakt telefoniczny, a także kontakt online, np. przez komunikator internetowy, dostęp do radia, telewizji i internetu ${ }^{9}$.

Problematyka kontaktów skazanych ze światem zewnętrznym została uregulowana $\mathrm{w}$ ustawodawstwie krajowym, przede wszystkim poprzez rozwiązania zawarte w Ustawie z dnia 6 czerwca 1997 r. Kodeks karny wykonawczy. Do tych unormowań należy zaliczyć m.in. art. 91, 92, 102, 105, 105a, 138, 139, 141a k.k.w. Wskazane regulacje zostaną omówione $\mathrm{w}$ treści niniejszego opracowania.

Podążając za kolejnością regulacji zawartych w Kodeksie karnym wykonawczym należy odnieść się do regulacji dotyczących liczby widzeń przysługujących skazanym w zależności od typu zakładu, w jakim odbywają karę pozbawienia wolności, tj. art. 90, 91, 91a, 92 k.k.w.

Sposób organizacji widzeń został szczegółowo uregulowany w art. 105a k.k.w. Widzenie trwa 60 minut. W widzeniu mogą uczestniczyć nie więcej niż 2 osoby pełnoletnie, chyba że dyrektor zakładu karnego, w uzasadnionych wypadkach, wyrazi zgodę na udział większej liczby osób. Liczba osób niepełnoletnich nie podlega ograniczeniu. Osoby niepełnoletnie mogą korzystać z widzeń tylko pod opieką osób pełnoletnich. Wskazać należy, że dni, godziny, miejsce i porządek przeprowadzania widzeń dyrektor zakładu karnego określa w porządku wewnętrznym zakładu, a jego

${ }^{8}$ A. KieszKowsKa: Problemy readaptacyjne osób opuszczajacych placówki resocjalizacyjne. „Probacja” 2009, nr 2, s. 102. https://www.arch.ms.gov.pl/Data/Files/_public/ probacja/2009/nr2/7kieszkowska.pdf [dostęp: 30.04.2020].

9 G.B. Szczygiet: Społeczna readaptacja skazanych..., s. 94. 
tekst powinien znajdować się w każdej celi mieszkalnej (§ 14 ust. 2 pkt 10 i $§ 17$ RegWykKPW $)^{10}$.

Istotne znaczenie ma okoliczność dotycząca typu zakładu karnego, $\mathrm{w}$ jakim dany skazany odbywa karę pozbawienia wolności, dlatego też niezbędne jest odwołanie się do dalszych regulacji Kodeksu karnego wykonawczego ${ }^{11}$. Widzenia skazanych niebezpiecznych ${ }^{12}$, odbywających karę pozbawienia wolności w oddziale lub celi zakładu karnego typu zamkniętego, odbywają się w miejscach do tego przeznaczonych, pod wzmocnionym dozorem. W trakcie widzeń skazani mogą być pozbawieni bezpośredniego kontaktu z osobą odwiedzającą, jeżeli zachodzi poważne zagrożenie bezpieczeństwa tychże osób - decyzję w tej sprawie podejmuje dyrektor zakładu karnego. W trakcie widzeń skazani nie mogą spożywać artykułów żywnościowych ani napojów. W zakładzie karnym typu zamkniętego (art. 90 k.k.w.) skazani mogą korzystać z 2 widzeń w miesiącu, które za zgodą dyrektora zakładu karnego mogą wykorzystać jednorazowo. Widzenia skazanych podlegają nadzorowi administracji zakładu karnego, zaś rozmowy skazanych w trakcie widzeń podlegają kontroli administracji zakładu karnego (podobne jak korespondencja oraz rozmowy telefoniczne $)^{13}$.

W zakładzie karnym typu półotwartego i otwartego organizacja widzeń jest odmienna. W zakładzie karnym typu półotwartego skazanym przysługują 3 widzenia w miesiącu, które (tak jak w przypadku widzeń w zakładzie karnym typu zamkniętego) za zgodą dyrektora jednostki penitencjarnej mogą zostać połączone. Zgodnie z treścią art. 91 pkt 9 k.k.w. widzenia skazanych podlegają nadzorowi administracji zakładu karnego; rozmowy skazanych w trakcie widzeń mogą podlegać kontroli administracji zakładu karnego. W zakładzie karnym typu otwartego, zgodnie z regulacją art. 92 pkt 10 i 11 k.k.w., skazany może korzystać z nieograniczonej liczby widzeń; widzenia mogą podlegać nadzorowi administracji zakładu karnego, natomiast rozmowy skazanych $\mathrm{w}$ trakcie widzeń nie podlegają kontroli administracji zakładu karnego ${ }^{14}$.

Jeśli chodzi o kwestię widzeń przewidzianych w wypadku zakładu karnego dla młodocianych (typu zamkniętego lub półotwartego), skazani

${ }^{10}$ Rozporządzenie Ministra Sprawiedliwości z dnia 21 grudnia 2016 r. w sprawie regulaminu organizacyjno-porządkowego wykonywania kary pozbawienia wolności. Dz.U. 2016 poz. 2231; S. Lelental: Kodeks karny wykonawczy. Komentarz. Warszawa 2020 [Legalis].

${ }^{11}$ S. LeLENTAL: Kodeks karny wykonawczy. Komentarz. Warszawa 2017, s. 456.

12 Art. 88 § 3 k.k.w. określa kategorię skazanych osadzanych w zakładzie karnym typu zamkniętego.

${ }^{13}$ Zob.: art. 88b § 1 pkt 9 k.k.w; S. LeLENTAL: Kodeks karny wykonawczy... (2017), s. 456 .

${ }^{14}$ K. Postulski: Kodeks karny wykonawczy. Komentarz. Warszawa 2017, s. 587. 
mają prawo do dodatkowego widzenia w miesiącu. Uprawnienie to dotyczy również skazanych dorosłych odbywających karę w zakładzie karnym dla młodocianych ${ }^{15}$.

W ślad za Stefanem Lelentalem należy wskazać, że przyznanie skazanym młodocianym uprawnienia $\mathrm{w}$ postaci dodatkowego widzenia $\mathrm{w}$ miesiącu ma na celu skuteczniejsze podtrzymywanie kontaktów z rodziną. Przedmiotowy środek oddziaływania penitencjarnego ma szczególne znaczenie w przypadku skazanych młodocianych, dlatego też nie sposób nie zgodzić się z Lelentalem, który postuluje, aby w odniesieniu do młodocianych „nie stosować kary dyscyplinarnej, o której stanowi przepis art. 143 $\S 1$ pkt $6 \mathrm{KKW}$, lub stosować ją wyjątkowo"16. Wskazana kara dyscyplinarna dotyczy udzielenia widzeń w sposób uniemożliwiający bezpośredni kontakt z osobą odwiedzającą, na okres do 3 miesięcy.

Omawiając problematykę widzeń skazanych z najbliższymi, należy odnieść się do regulacji zawartej w art. $105 \mathrm{a} \$ 3$ k.k.w. W myśl tego przepisu skazani, o których mowa w art. 87a $\$ 1 \mathrm{k} \cdot \mathrm{k} \cdot \mathrm{w}^{17}$, mają prawo do dodatkowego widzenia z dziećmi. Regulacja ta jednak nie jest doprecyzowana, gdyż nie wskazano częstotliwości takich widzeń. Na podstawie tego, że wyznaczony okres, w jakim przysługuje liczba widzeń stosowna dla zakładu karnego typu zamkniętego oraz półotwartego, to okres miesięczny, można wnioskować, iż dodatkowe widzenie przysługuje co miesiąc ${ }^{18}$.

Regulacje dotyczące praw osób skazanych prezentują różne zwroty zastosowane przez ustawodawcę $\mathrm{w}$ procesie ich tworzenia - począwszy od przepisu art. 102 k.k.w., w którym to określono expressis verbis niektóre prawa osoby skazanej, stosując zwrot „skazany ma prawo”, skończywszy na określeniach „skazany może”. Prawo skazanych do kontaktów ze światem zewnętrznym, zgodnie z art. 102. pkt 2, 7 i 11 k.k.w., oparte jest w szczególności na utrzymywaniu więzi z rodziną i innymi osobami bliskimi, komunikowaniu się z obrońcą, pełnomocnikiem, właściwym kuratorem sądowym oraz wybranym przez siebie przedstawicielem, a także prowadzeniu korespondencji z organami ścigania, wymiaru sprawiedliwości i innymi organami państwowymi, organami samorządu terytorialnego, Rzecznikiem Praw Obywatelskich, Rzecznikiem Praw Dziecka oraz or-

15 W. FRIEDRICH: Wychowawczo-resocjalizacyjne środki oddziatywania..., s. 283; S. LELENTAL: Kodeks karny wykonawczy... (2020).

16 S. LeLENTAL: Kodeks karny wykonawczy... (2020).

17 Zgodnie z art. 87a § 1 k.k.w.: „Wykonując karę wobec skazanych sprawujących stałą pieczę nad dzieckiem do lat 15, uwzględnia się w szczególności potrzebę inicjowania, podtrzymywania i zacieśniania ich więzi uczuciowej z dziećmi, wywiązywania się z obowiązków alimentacyjnych oraz świadczenia pomocy materialnej dzieciom, a także współdziałania z placówkami opiekuńczo-wychowawczymi, w których te dzieci przebywają”.

${ }^{18}$ J. Potulski: Rozdział X: Kara pozbawienia wolności. Nb. 1-4. W: Kodeks karny wykonawczy. Komentarz. Red. J. LachowsKi. Warszawa 2016, s. 481. 
ganami powołanymi na podstawie ratyfikowanych przez Rzeczpospolita Polską umów międzynarodowych dotyczących ochrony praw człowieka. Dodatkowo wskazać należy, że w ramach prawa do utrzymywania więzi $\mathrm{z}$ rodziną i innymi osobami bliskimi zawiera się także prawo do otrzymywania paczek żywnościowych ${ }^{19}$.

Regulacja zawarta w art. $105 \S 1$ k.k.w. nawiązuje do treści art. 67 § 3 k.k.w., zgodnie z którym podtrzymywanie kontaktów z szeroko rozumianym światem zewnętrznym należy do środków oddziaływania penitencjarnego. Poprzez takie oddziaływania realizowany jest cel wykonywania kary pozbawienia wolności ${ }^{20}$. Ustawodawca poprzez unormowania $\mathrm{z}$ art. $105 \S 1-3$ k.k.w. przyznaje skazanym uprawnienia zgodne ze standardami wynikającymi z Europejskich Reguł Więziennych, postulujące podejmowanie działań zapobiegających zerwaniu przez skazanych więzi ze światem zewnętrznym, co jest odzwierciedleniem przestrzegania zasady humanitarnego wykonywania kary pozbawienia wolności. Kontakty skazanego z bliskimi są elementem niezbędnym w przygotowaniu do powrotu do życia na wolności oraz readaptacji w społeczeństwie. Do form, $\mathrm{w}$ jakich przejawia się prawo do kontaktów ze światem zewnętrznym, należy zaliczyć widzenia, korespondencję, rozmowy telefoniczne, paczki, przekazy pieniężne, a także inne środki łączności, które są dostępne wyłącznie w uzasadnionych przypadkach i za zgodą dyrektora jednostki penitencjarnej ${ }^{21}$.

W treści Europejskich Reguł Więziennych (reguły 24.1, 24.2, 24.3) wskazano zasady umożliwiające osobom pozbawionym wolności utrzymywanie kontaktu ze światem zewnętrznym. Najważniejszy element tegoż uprawnienia stanowi prawo porozumiewania się z taką częstotliwością, jaka tylko jest możliwa, poprzez realizację różnych form kontaktu (listy, rozmowy telefoniczne i inne formy komunikacji). Porozumiewanie się dotyczy kontaktu z rodziną, innymi osobami, a także z przedstawicielami organizacji zewnętrznych oraz odwiedzin tychże osób ${ }^{22}$. Jedną z najważniejszych form utrzymywania kontaktów przez skazanych są widzenia, z uwagi na możliwość bezpośrednich kontaktów z bliskimi i ze światem zewnętrznym. Zgodnie z regułą numer 24.4 Europejskich Reguł Więziennych sposób wizyt winien pozwalać więźniom na utrzymywanie

19 S. LeLENTAL: Kodeks karny wykonawczy... (2020).

20 S. LeLENTAL: Kodeks karny wykonawczy... (2017), s. 453.

${ }^{21}$ K. PostulsKi: Kodeks karny wykonawczy..., s. 582.

${ }^{22}$ Rekomendacja Rec (2006) 2 Komitetu Ministrów do państw członkowskich Rady Europy w sprawie Europejskich Reguł Więziennych. http://www.bip.sw.gov.pl/ SiteCollectionDocuments/CZSW/prawaczl/document.pdf [dostęp: 2.02.2021]; J. PotULSKI: Kodeks karny wykonawczy..., s. 478. 
i rozwijanie więzi rodzinnych w normalny sposób - „tak jak tylko jest to możliwe".

Odnosząc się do podstaw reguły 24, należy przywołać unormowania wynikające z art. 8 Europejskiej Konwencji Praw Człowieka (ECHR), tj. Konwencji o Ochronie Praw Człowieka i Podstawowych Wolności²3. Zgodnie $\mathrm{z}$ owym unormowaniem każdy ma prawo do poszanowania swojego życia prywatnego i rodzinnego, swojego mieszkania i swojej korespondencji. Jak zastrzeżono w art. 8 ust. 2 ECHR, niedopuszczalna jest ingerencja władzy publicznej w korzystanie $\mathrm{z}$ tego prawa $\mathrm{z}$ wyjątkiem przypadków przewidzianych przez ustawę i koniecznych w demokratycznym społeczeństwie z uwagi na bezpieczeństwo państwowe, bezpieczeństwo publiczne lub dobrobyt gospodarczy kraju, ochronę porządku i zapobieganie przestępstwom, ochronę zdrowia i moralności lub ochronę praw i wolności osób ${ }^{24}$.

W związku z owymi regulacjami i problematyką praw skazanych do kontaktów ze światem zewnętrznym, ze stanowiska reprezentowanego przez Europejski Trybunał Praw Człowieka ${ }^{25}$ należy wnioskować, że zasadniczą częścią prawa więźniów do poszanowania życia rodzinnego jest umożliwienie im przez władze utrzymywania kontaktu z najbliższą rodziną lub, w razie potrzeby, pomoc w tej kwestii. Wszelkie ograniczenia $\mathrm{w}$ tym zakresie muszą być zgodne z prawem, służyć uprawnionemu celowi i być proporcjonalne, zgodnie z wymogami art. 8 ust. $2 \mathrm{ECHR}^{26}$.

Utrzymywanie więzi z bliskimi ma na celu wzbudzanie w skazanym poczucia nieprzerwanej przynależności do określonego środowiska, rodziny, co stanowi niezwykle istotny czynnik zapobiegający prizoniacji. Kontakty z bliskimi budują poczucie bezpieczeństwa skazanych oraz wpływają na prawidłowe zaspokajanie potrzeb uczuciowych ${ }^{27}$. Warto podkreślić, że pojęcie rodziny i innych osób bliskich zawarte w treści art. 102 pkt 2 k.k.w. nie jest tożsame z definicją zawartą w art. 115 § 11 k.k., któ-

${ }^{23}$ Europejska Konwencja Praw Człowieka. Council of Europe. https://www.echr.coe. int/Documents/Convention_POL.pdf [dostęp: 30.04.2021]; Konwencja o Ochronie Praw Człowieka i Podstawowych Wolności sporządzona w Rzymie dnia 4 listopada 1950 r., zmieniona następnie Protokołami nr 3, 5 i 8 oraz uzupełniona Protokołem nr 2. Dz.U. $1993 \mathrm{nr} 61$ poz. 284.

${ }^{24}$ Komentarz do Europejskich Reguł Więziennych. Council of Europe. https://search. coe.int/cm/Pages/result_details.aspxObjectId=09000016809c9086 [dostęp: 23.04.2021].

${ }_{25}$ Zob. np. Case of Polyakova and others v. Russia, Applications nos. 35090/09 and 3 others. European Court of Human Rights. https:/hudoc.echr.coe.int/ eng\#\{“itemid”:[“001-171774”]\} [dostęp: 30.04.2021].

${ }^{26}$ Komentarz do Europejskich Reguł Więziennych...

27 K. DĄBKIEwICZ: Kodeks karny wykonawczy. Komentarz. Warszawa 2015, s. 462; T. Szymanowski: Prawo karne wykonawcze z elementami polityki karnej i penitencjarnej. Warszawa 2017, s. 337. 
ry w tym przypadku nie ma zastosowania ${ }^{28}$. Katalog grupy osób bliskich i członków rodziny, wynikający z art. 102 pkt 2 Kodeksu karnego wykonawczego, jest szerszy od katalogu wskazanego w Kodeksie karnym, gdyż bliskość relacji oparta jest na sytuacji faktycznej danego przypadku, a nie jedynie na regulacji ustawowej ${ }^{29}$.

\section{Kontakty ze światem zewnętrznym w ramach przyznanej nagrody - refleksje na tle art. 138 k.k.w.}

Poruszając tematykę kontaktów skazanych ze światem zewnętrznym, a w szczególności realizację tego uprawnienia poprzez widzenia z członkami rodziny i innymi bliskimi osobami, należy odnieść się również do art. 138 k.k.w., który to zawiera katalog nagród przyznawanych skazanym. Istotne znaczenie odgrywa nagroda wymieniona w art. $138 \S 1$ pkt 3 k.k.w., tj. zezwolenie na widzenie w oddzielnym pomieszczeniu bez osoby dozorującej. W ramach tej nagrody możliwe jest odbycie spotkania na przykład z partnerem, rodzicami, dziećmi, rodzeństwem ${ }^{30}$. Widzenia tego typu powinny odbywać się bez stosowania monitoringu ${ }^{31}$. Możliwość takiego spotkania przyczynia się więc m.in. do utrzymywania więzi małżeńskich bądź więzi w związku partnerskim, z uwagi na umożliwienie nawiązania kontaktu seksualnego ${ }^{32}$. Nagroda może być przyznana skazanym odbywającym karę pozbawienia wolności w każdym z rodzajów i typów zakładów, jednakże możliwość ograniczenia $\mathrm{w}$ tym zakresie występuje w przypadku skazanych stwarzających poważne zagrożenie. Widzenia te mogą być przyznawane na zasadach ogólnych dotyczących widzeń.

Dokonując analizy problematyki kontaktu skazanych ze światem zewnętrznym, należy zauważyć, że w przypadku widzeń realizowanych $\mathrm{w}$ ramach nagrody z art. $138 \S 1$ pkt 3 k.k.w. pojawiają się trudności związane $\mathrm{z}$ brakiem pomieszczeń dostosowanych do widzeń $\mathrm{w}$ oddzielnym pomieszczeniu bez osoby dozorującej. W raporcie Krajowego Mechanizmu Prewencji za 2016 r. słusznie wskazano, że „brak pomieszczenia do reali-

${ }^{28}$ Ustawa z dnia 6 czerwca 1997 r. Kodeks karny. Dz.U. 1997 nr 88 poz. 553 z poźn. zm.; zgodnie z art. 115 § 11 k.k. osobą najbliższą jest małżonek, wstępny, zstępny, rodzeństwo, powinowaty w tej samej linii lub stopniu, osoba pozostająca w stosunku przysposobienia oraz jej małżonek, a także osoba pozostająca we wspólnym pożyciu.

${ }^{29}$ K. Postulski: Kodeks karny wykonawczy..., s. 578.

${ }^{30}$ I. Zgoliński: Rozdział X: Kara pozbawienia wolności. Nb. 8. W: Kodeks karny wykonawczy. Komentarz. Red. J. LachowsKi. Warszawa 2016, s. 545.

${ }^{31}$ K. Postulski: Kodeks karny wykonawczy..., s. 681.

32 S. LeLENTAL: Kodeks karny wykonawczy... (2017), s. 557. 
zacji nagrody uniemożliwia w praktyce jej udzielenie, nawet w przypadku spełnienia przez osadzonych warunków do jej przyznania" ${ }^{33}$. Brak takich sal stwierdzono m.in. w Areszcie Śledczym w Lublinie oraz Areszcie Śledczym w Sanoku. Ponadto Krajowy Mechanizm Prewencji nadal odnotowuje przypadki organizacji widzeń bez osoby dozorującej w pomieszczeniach wyposażonych w kamery monitoringu wizyjnego (Areszt Śledczy Nowa Sól, Areszt Śledczy Lublin, Areszt Śledczy Gdańsk, Zakład Karny Stare Borne, Oddział Zewnętrzny w Goleszach), co stanowi zaprzeczenie idei tego typu widzeń. W miejscach stwierdzenia nieprawidłowości zalecono demontaż kamer lub zakładanie na nie trwałych przesłon na czas widzenia ${ }^{34}$.

W Raporcie Rzecznika Praw Obywatelskich z działalności Krajowego Mechanizmu Prewencji Tortur $w$ roku 2019, w zakresie realizacji nagrody w postaci widzeń bezdozorowych, wskazano, że w jednej z monitorowanych jednostek sala przewidziana do odbywania owych widzeń nie był wyposażona zgodnie $\mathrm{z}$ regulacjami zawartymi w Załączniku nr 3 (Tabela 17) do Rozporządzenia Ministra Sprawiedliwości z dnia 19 grudnia 2016 r. w sprawie warunków bytowych osób osadzonych w zakładach karnych i aresztach śledczych (Dz.U. 2016 poz. 2224). Dodatkowo jedna z kontrolowanych jednostek posiadała zainstalowany system monitoringu w sali tego typu, co uznano za dalece niewłaściwe, przeczące idei widzeń bez dozoru. Podkreślono, że zabiegiem koniecznym do przywrócenia ustawowego charakteru przedmiotowej nagrody jest rezygnacja z monitorowania tego typu widzeń ${ }^{35}$.

Znaczenie dla realizacji uprawnienia do kontaktów skazanych ze światem zewnętrznym mają także nagrody określone w art. 138 § 1 pkt 7 i 8 k.k.w. Zezwolenie na opuszczenie zakładu karnego bez dozoru, na okres nieprzekraczający jednorazowo $14 \mathrm{dni}$, nie tylko stanowi najwyższą nagrodę, ale także daje możliwość realizacji omawianego uprawnienia ${ }^{36}$. Czas przebywania skazanego poza jednostką penitencjarną w ramach przyznawanych nagród w postaci czasowego opuszczenia zakładu karnego zalicza się do okresu odbywania kary. Jednakże może wystąpić w tym zakresie wyjątek, w przypadku nadużycia udzielonego zaufania i odmiennego zarządzenia sędziego penitencjarnego ${ }^{37}$.

33 „Biuletyn RPO. Źródła” 2017, nr 4: Raport Rzecznika Praw Obywatelskich z działalności w Polsce Krajowego Mechanizmu Prewencji Tortur w roku 2016, s. 42

${ }^{34}$ Ibidem; „Biuletyn RPO. Źródła” 2019: Raport Rzecznika Praw Obywatelskich z dziatalności w Polsce Krajowego Mechanizmu Prewencji Tortur w roku 2018, s. 151.

35 „Biuletyn RPO. Źródła” 2020, nr 3: Raport Rzecznika Praw Obywatelskich z działalności w Polsce Krajowego Mechanizmu Prewencji Tortur w roku 2019, s. 91.

36 S. LeLENTAL: Kodeks karny wykonawczy... (2017), s. 558.

37 I. Zgoliński: Rozdział X: Kara pozbawienia wolności..., s. 545. 


\section{Korespondencja oraz dostęp do aparatu telefonicznego}

Kontakty ze światem zewnętrznym utrzymywane są również dzięki wymianie korespondencji. Odwołując się do regulacji art. 8a § 1 k.k.w., podnieść należy, iż korespondencja skazanego podlega cenzurze i nadzorowi, chyba że ustawa stanowi inaczej. Nie podlega cenzurze, nadzorowi ani zatrzymaniu korespondencja skazanego pozbawionego wolności prowadzona $\mathrm{z}$ obrońca lub pełnomocnikiem będącym adwokatem lub radcą prawnym, a także $\mathrm{z}$ organami ścigania, wymiaru sprawiedliwości i innymi organami państwowymi, organami samorządu terytorialnego, Rzecznikiem Praw Obywatelskich, Rzecznikiem Praw Dziecka, organami powołanymi na podstawie ratyfikowanych przez Rzeczpospolitą Polską umów międzynarodowych dotyczących ochrony praw człowieka oraz przedstawicielem nie będącym adwokatem ani radcą prawnym, który został zaaprobowany przez przewodniczącego Izby Europejskiego Trybunału Praw Człowieka do reprezentowania skazanego przed tym Trybunałem. W konsekwencji należy przyjąć, że cenzura nie jest dopuszczalna nie tylko $\mathrm{z}$ uwagi na okoliczności wprost wynikające $\mathrm{z}$ ustawy, ale również w sytuacji, gdy ustawa nie zawiera regulacji w tym zakresie ${ }^{38}$. Do kwestii korespondencji odnoszą się również Europejskie Reguły Więzienne; zgodnie $\mathrm{z}$ regułą 23.4 konsultacje oraz inna komunikacja, w tym korespondencja na tematy prawne pomiędzy więźniami a ich obrońcami, jest poufna.

Podobnie jak w przypadku widzeń, stosowanie cenzury korespondencji jest uzależnione od typu zakładu karnego, w którym skazany odbywa karę. W zakładzie karnym typu zamkniętego korespondencja podlega cenzurze, z wyłączeniem korespondencji podlegającej jedynie nadzorowi, wskazanej w art. 8 § 3 k.k.w. oraz art. 102 pkt 11 k.k.w. W zakładzie karnym typu półotwartego korespondencja może podlegać cenzurze, a w zakładzie karnym typu otwartego jej nie podlega ${ }^{39}$. Ponadto w regule 24.2 Europejskich Reguł Więziennych wskazano: „[...] komunikacja i wizyty mogą być poddane ograniczeniom i monitoringowi potrzebnym dla kontynuacji śledztwa, utrzymania porządku i bezpieczeństwa, zapobiegania przestępstwom karnym oraz ochrony ofiar przestępstwa, jednak takie ograniczenia, włączając $\mathrm{w}$ to określone ograniczenia wprowadzone przez władze sądowe, będą jednak przewidywać dopuszczalny minimalny kontakt".

Dyrektor zakładu karnego, bez względu na typ zakładu karnego, w jakim skazany odbywa karę pozbawienia wolności, może podejmować decyzje dotyczące zatrzymania otrzymywanych i przesyłanych paczek,

${ }^{38}$ K. Postulski: Kodeks karny wykonawczy..., s. 583.

39 Ibidem, s. 584. 
a także ich zniszczenia jedynie $\mathrm{w}$ przypadkach przewidzianych $\mathrm{w}$ treści regulacji art. $105 \$ 6$ k.k.w. Przedmiotowe decyzje powinni dotyczyć jedynie wyjątkowych sytuacji, wymagających takiego działania ze względów bezpieczeństwa zakładu lub porządku publicznego. Dyrektor powiadamia o takiej decyzji sędziego penitencjarnego oraz skazanego ${ }^{40}$. Dostarczona do zakładu karnego paczka, przed przekazaniem jej odpowiedniemu skazanemu, podlega kontroli, która przeprowadzana jest także za pomocą odpowiednich urządzeń technicznych i środków - w tym poprzez wykorzystanie odpowiednio szkolonych psów ${ }^{41}$.

Niezwykle istotne znaczenie ma również możliwość wykonywania rozmów telefonicznych. Przepis art. 105b k.k.w. dotyczy kwestii dostępu do telefonu - skazany ma bowiem prawo korzystać z samoinkasującego aparatu telefonicznego na własny koszt lub na koszt rozmówcy. Ponadto, zgodnie z § 2 tego artykułu, w uzasadnionych wypadkach dyrektor zakładu karnego może zezwolić skazanemu na skorzystanie $\mathrm{z}$ innego aparatu na koszt rozmówcy lub skazanego, a jeżeli skazany nie posiada środków pieniężnych, na koszt zakładu karnego. Przez pojęcie „innego aparatu" należy rozumieć aparat komórkowy lub aparat stacjonarny zakładu karnego ${ }^{42}$.

Podobnie jak w zakresie widzeń oraz korespondencji, w zależności od typu zakładu karnego, rozmowy telefoniczne podlegają kontroli administracji zakładu (art. 90 pkt 9 k.k.w.; zakład typu zamkniętego), mogą podlegać wskazanej kontroli (art. 91 pkt 11 k.k.w.; zakład typu półotwartego), a nawet mogą być wyłączone spod owej kontroli (art. 92 pkt 14 k.k.w.; zakład typu otwartego). Wskazana kontrola obejmuje nie tylko zapoznanie się z treścią rozmowy, ale również możliwość jej przerwania lub utrwalenia, co jednoznacznie wynika z art. $242 \S 10$ k.k.w. ${ }^{43}$. Natomiast zgodnie z art. $247 \S 1$ k.k.w. dyrektor zakładu karnego, w przypadkach uzasadnionych szczególnymi względami sanitarnymi lub zdrowotnymi albo poważnym zagrożeniem bezpieczeństwa, może na określony czas wstrzymać korzystanie z samoinkasujących aparatów telefonicznych.

Dokonując analizy zagadnienia kontaktów skazanych ze światem zewnętrznym, należy odnieść się również do Rozporządzenia Ministra Sprawiedliwości z dnia 21 grudnia 2016 r. w sprawie regulaminu organizacyjno-porządkowego wykonywania kary pozbawienia wolności. Zgodnie z § 24 Rozporządzenia skazany może skorzystać z samoinka-

${ }^{40}$ Ibidem.

${ }^{41}$ S. LeLENTAL: Kodeks karny wykonawczy... (2017), s. 454; zob. § 33 Rozporządzenia Ministra Sprawiedliwości z 21 grudnia 2016 r. w sprawie regulaminu organizacyjno-porządkowego wykonywania kary pozbawienia wolności, Dz. U. 2016, poz. 2231.

42 K. Postulski: Kodeks karny wykonawczy..., s. 589.

${ }^{43}$ S. LeLENTAL: Kodeks karny wykonawczy... (2017), s. 458. 
sującego aparatu telefonicznego jeden raz w ciągu dnia. W uzasadnionych przypadkach dyrektor może zezwolić skazanemu na przeprowadzenie dodatkowej rozmowy. W porządku wewnętrznym zakładu karnego typu półotwartego lub otwartego można określić większą częstotliwość korzystania przez skazanego z samoinkasującego aparatu telefonicznego. Realizacja rozmów telefonicznych następuje w kolejności zgłoszeń, a czas korzystania z aparatu telefonicznego, z wyłączeniem rozmów z podmiotami, o których mowa w art. $8 \S 3$ k.k.w., jednorazowo nie może przekraczać 5 minut. Jednakże porządek wewnętrzny zakładu karnego może przewidywać dłuższy czas korzystania z aparatu telefonicznego ${ }^{44}$.

\section{Nowe środki komunikacji ze światem zewnętrznym}

Dążąc do realizacji standardów międzynarodowych wykonywania kary w zakresie realizacji prawa skazanych do kontaktów ze światem zewnętrznym, w kwietniu 2014 roku rozpoczęto realizację programu pilotażowego, w ramach którego w kilkunastu jednostkach penitencjarnych wprowadzono możliwość utrzymywania przez skazanych dodatkowych kontaktów z bliskimi za pomocą komunikatora internetowego Skype. Przedstawiciele Krajowego Mechanizmu Prewencji wysoko oceniają możliwość utrzymywania przez skazanych dodatkowych kontaktów w tej formie, która obecnie jest dostępna we wszystkich placówkach. Zgodnie $\mathrm{z}$ założeniami programu preferencje $\mathrm{w}$ korzystaniu ze Skype’a maja cudzoziemcy przebywający w polskich jednostkach penitencjarnych oraz ci skazani, których rodziny zamieszkują na terenie Polski lub za granicą w odległości uniemożliwiającej systematyczny kontakt bezpośredni. Pozytywna ocena Krajowego Mechanizmu Prewencji wiąże się również z dużą funkcjonalnością tej formy komunikacji. Popierany jest jej rozwój i postulowana jest jej dostępność także dla innych niż wymienione grup skazanych ${ }^{45}$. Podkreśla się również istotę przekazywania skazanym informacji o możliwości prowadzenia wirtualnych rozmów przez program Skype przy przyjęciu do jednostki oraz za pomocą radiowęzła czy telewizji wewnętrznej ${ }^{46}$.

${ }_{44}$ Rozporządzenie Ministra Sprawiedliwości z dnia 21 grudnia 2016 r. w sprawie regulaminu organizacyjno-porządkowego wykonywania kary pozbawienia wolności. Dz.U. 2016, poz. 2231.

45 „Biuletyn RPO. Źródła” 2015, nr 4: Raport Rzecznika Praw Obywatelskich z działalności w Polsce Krajowego Mechanizmu Prewencji w roku 2014, s. 23.

46 „Biuletyn RPO. Źródła” 2017, nr 4: Raport Rzecznika Praw Obywatelskich z dziatalności w Polsce Krajowego Mechanizmu Prewencji Tortur w roku 2016, s. 41. 
Ponadto wśród działań podejmowanych przez administracje zakładów karnych i aresztów śledczych wizytowanych przez Krajowy Mechanizm Prewencji wyróżnia się i wskazuje jako godne polecenia te działania, które ułatwiają nawiązywanie kontaktów z bliskimi przez nowe środki komunikacji. W raporcie z działalności Krajowego Mechanizmu Prewencji za 2015 r. do dobrych praktyk zaliczono m.in. tzw. kioski internetowe, wyposażone $\mathrm{w}$ akcesoria (kamera, mikrofon, słuchawka) niezbędne do realizacji wskazanych już wideorozmów za pośrednictwem komunikatora internetowego przez osoby pozbawione wolności. Jest to rozwiązanie zastosowane w oddziałach mieszkalnych Zakładu Karnego w Sierakowie Śląskim. Podkreślono, że dzięki zainstalowaniu kiosków w każdym z oddziałów dostęp do tej formy kontaktu jest powszechny ${ }^{47}$.

Przytoczone stanowiska Krajowego Mechanizmu Prewencji stanowią jedne z wielu opinii pokontrolnych, gdyż z uwagi na doniosłe znaczenie prawa skazanych do kontaktu ze światem zewnętrznym oraz utrzymywania więzi z rodziną uprawnienie to jest stałym przedmiotem kontroli przeprowadzanych przez Krajowy Mechanizm Prewencji.

\section{Nagrody wolnościowe i zezwolenie na opuszczenie zakładu - art. 139 i 141 a k.k.w.}

Omawiając czynniki mające wpływ na utrzymanie kontaktów ze światem zewnętrznym, należy odnieść się również do przepustek i zezwoleń, które przyznawane są skazanym w określonych okolicznościach. Kodeks karny wykonawczy przewiduje przepustki na podstawie regulacji zawartych $\mathrm{w}$ art. 91 pkt 7 oraz art. 92 pkt 9, regulacji dotyczących nagrody określonych w art. 138 § 1 pkt 7 i 8, zezwoleń z art. 139, a także te wydawane z ważnych przyczyn (art. 141a) oraz te, które mają na celu przygotowanie do zwolnienia (art. 165 §).

Każda z wymienionych regulacji pozwala na bezpośrednie realizowanie prawa do kontaktów ze światem zewnętrznym, jest zatem niezwykle istotna, jednakże z uwagi na ograniczone ramy niniejszego opracowania brak jest możliwości kompleksowego przedstawienia wszystkich zagadnień. Pokrótce zostały omówione te, które zdaniem autorki są najistotniejsze.

Zgodnie z treścią art. 138 § 1 pkt 7 i 8 k.k.w. nagrodami są: zezwolenie na widzenie bez dozoru, poza obrębem zakładu karnego, z osobą najbliższą lub osobą godną zaufania, na okres nieprzekraczający jednorazowo

47 „Biuletyn RPO. Źródła” 2016, nr 4: Raport Rzecznika Praw Obywatelskich z działalności w Polsce Krajowego Mechanizmu Prewencji w roku 2015, s. 18. 
30 godzin oraz zezwolenie na opuszczenie zakładu karnego bez dozoru, na okres nieprzekraczający jednorazowo $14 \mathrm{dni}$.

W myśl art. 139 § 1 k.k.w. podstawą przyznania skazanemu którejkolwiek ze wspomnianych nagród jest uzasadnione przypuszczenie, że w czasie pobytu poza zakładem karnym będzie przestrzegał porządku prawnego. W celu potwierdzenia zasadności przypuszczenia co do zachowania danego skazanego należy odnieść się do okoliczności związanych nie tylko z wyróżnianiem się przez skazanego dobrym zachowaniem (art. 137 k.k.w.), ale także z postawą reprezentowaną w czasie odbywania kary. W sytuacji przyznania nagrody $\mathrm{w}$ postaci zezwolenia na widzenie bez dozoru, poza obrębem zakładu karnego, niezwykle istotne jest także uwiarygodnienie przez skazanego, że widzenie odbędzie się z osobą najbliższą lub godną zaufania ( $\$ 46$ RegWykKPW) ${ }^{48}$.

W tym miejscu należy, w ślad za Lelentalem, wskazać, że termin „postawa skazanego” nosi znamiona ogólności w takim stopniu, że niezwykle trudno jest o jego precyzyjne zdefiniowanie. W niezwykle bogatym orzecznictwie Sądu Najwyższego i sądów apelacyjnych dotyczącym stosowania tej instytucji, nie odwoływano się do tej przesłanki ${ }^{49}$.

Zgodnie z regulacjami ustawowymi łączna liczba nagród wymienionych $\mathrm{w}$ art. $138 \S 1$ pkt 7 przyznanych skazanemu nie może przekroczyć 28 nagród w roku, a łączny czas trwania widzeń w ramach tychże nie może przekroczyć 28 dni w roku. Ponadto skazanemu odbywającemu karę dożywotniego pozbawienia wolności nagroda wymieniona w art. 138 § 1 pkt 7 lub 8 może być przyznana po odbyciu co najmniej 15 lat kary, zaś przyznanie takiej nagrody skazanemu odbywającemu karę 25 lat pozbawienia wolności albo karę dożywotniego pozbawienia wolności w zakładzie karnym typu zamkniętego wymaga zgody sędziego penitencjarnego.

Istotne pozostają jeszcze dwie kwestie - zezwolenia na opuszczenie zakładu ze względu na przyczyny losowe, a także na opuszczenie zakładu celem przygotowania się do zwolnienia.

W pierwszym omawianym przypadku, uregulowanym w treści art. 141a k.k.w., dyrektor zakładu karnego może udzielić skazanemu zezwolenia na opuszczenie zakładu karnego pod konwojem funkcjonariusza Służby Więziennej, osoby godnej zaufania lub samodzielnie, na czas nieprzekraczający 5 dni, w celu odwiedzenia poważnie chorego członka rodziny, uczestnictwa w pogrzebie członka rodziny lub w innych okolicznościach szczególnie ważnych dla skazanego.

48 S. LeLENTAL: Kodeks karny wykonawczy... (2020).

${ }^{49}$ Ibidem. 
Wskazane zezwolenie nazywane jest także przepustką losową, chociaż oprócz sytuacji losowych dotyczy również sytuacji szczególnie ważnych dla skazanego. Istotne jest to, że przebywanie skazanego pod konwojem funkcjonariusza Służby Więziennej czy też w asyście osoby godnej zaufania ograniczane jest do minimum, gdyż trudno sobie wyobrazić konwojowanie czy asystę trwającą maksymalny dopuszczalny czas przedmiotowego zwolnienia, tj. 5 dni, dlatego też opuszczenie przez skazanego zakładu karnego na podstawie przepisów art. 141a k.k.w. udzielane jest co do zasady bez konwoju czy asysty ${ }^{50}$.

Odnosząc się dodatkowo do instytucji zezwolenia na opuszczenie zakładu karnego celem przygotowania się do zwolnienia (art. 165 $\S 2$ k.k.w.), wskazać należy, że łączny czas takiego zwolnienia może wynosić 14 dni. W tym czasie skazany podejmuje starania o uzyskanie po zwolnieniu odpowiednich możliwości zamieszkania i pracy. Zezwolenie na opuszczenie zakładu można przyznać skazanemu, którego postawa $\mathrm{w}$ czasie odbywania kary uzasadnia przypuszczenie, że w czasie pobytu poza zakładem karnym będzie przestrzegał porządku prawnego.

\section{Ocena realizacji prawa skazanych do kontaktów ze światem zewnętrznym - raporty Krajowego Mechanizmu Prewencji oraz orzecznictwo Europejskiego Trybunału Praw Człowieka}

W raporcie za 2012 r. wskazano, że realizacja omawianego prawa została oceniona pozytywnie, jednakże niektóre $\mathrm{z}$ wizytowanych jednostek nie wyodrębniły pomieszczenia przeznaczonego do odbywania widzeń bez osoby dozorującej, co uniemożliwia realizację tego uprawnienia. Dodatkowo wskazano placówki, w których wprowadzono zakaz prowadzenia rozmów telefonicznych z obrońcą lub pełnomocnikiem przez osoby tymczasowo aresztowane - należały do nich m.in. Areszt Śledczy w Grójcu, Areszt Śledczy w Mysłowicach, Zakład Karny w Wadowicach, Zakład Karny w Sieradzu. Taka procedura ogranicza prawo do kontaktu ze światem zewnętrznym oraz narusza przepis art. $215 \S 1 \mathrm{zd}$. 1 k.k.w, zgodnie z którym: „Tymczasowo aresztowany ma prawo do porozumiewania się z obrońcą, pełnomocnikiem będącym adwokatem albo radcą prawnym oraz przedstawicielem niebędącym adwokatem ani radcą prawnym, który został zaaprobowany przez Przewodniczącego Izby Europejskiego Trybunału Praw Człowieka do reprezentowania skazanego przed tym Trybunałem, podczas nieobecności innych osób oraz korespondencyj-

${ }^{50}$ S. LELENTAL: Kodeks karny wykonawczy... (2020). 
nie”. W konsekwencji wykrycia nieprawidłowości zalecono ich usunięcie poprzez „umożliwienie tymczasowo aresztowanym prowadzenia rozmów telefonicznych $\mathrm{z}$ obrońcą lub pełnomocnikiem oraz uwzględnienie tego uprawnienia $\mathrm{w}$ porządku wewnętrznym jednostek, zorganizowanie pomieszczenia do odbywania widzenia, bez osoby dozorującej" ${ }^{51}$.

Jako problem systemowy w raporcie dotyczącym 2014 r. stwierdzono w wypadku niektórych zakładów karnych brak możliwości kontaktów telefonicznych osób tymczasowo aresztowanych z ich obrońcami lub pełnomocnikami. Jednakże raport ten zawiera również informacje o mocnych stronach i dobrych praktykach jednostek penitencjarnych; zaliczono do nich udostępnienie od kwietnia 2014 r. komunikatora internetowego osadzonym cudzoziemcom i osobom pozbawionym systematycznego kontaktu z rodziną - do utrzymywania dodatkowych kontaktów z bliskimi, umieszczenie budek telefonicznych w Areszcie Śledczym w Zabrzu, zapewniających poszanowanie prawa do prywatności podczas odbywania rozmów telefonicznych ${ }^{52}$.

W polskim systemie penitencjarnym na przestrzeni lat dokonano istotnych zmian dotyczących sposobu funkcjonowania i realizowania uprawnienia do kontaktów ze światem zewnętrznym, czego dowodem są raporty Krajowego Mechanizmu Prewencji. Jednakże stwierdzono również liczne naruszenia tego prawa, co skutkowało skierowaniem do Europejskiego Trybunału Praw Człowieka wielu skarg przeciwko Polsce z tytułu naruszenia art. 8 Europejskiej Konwencji Praw Człowieka, czyli prawa do poszanowania życia rodzinnego i prywatnego. Ograniczone ramy niniejszego opracowania pozwalają jedynie na wskazanie przykładowych skarg, które dotyczyły różnych naruszeń z zakresu prawa skazanych do kontaktów ze światem zewnętrznym. Wymieńmy skargi skierowane w sprawach:

- Wegera przeciwko Polsce (skarga nr 141/07) w związku z nałożonymi ograniczeniami w zakresie kontaktów skarżącego z rodziną;

- Friedensberg przeciwko Polsce (skarga nr 44025/08), w związku z cenzurą korespondencji;

- Jarkiewicz przeciwko Polsce (skarga nr 23623/07), w związku z cenzurą korespondencji;

- Mazgaj przeciwko Polsce (skarga nr 41656/02), w związku z ograniczeniem możliwości kontaktu z osobami najbliższymi w czasie stosowania środka zapobiegawczego w postaci tymczasowego aresztowania;

51 „Biuletyn RPO. Źródła” 2012, nr 5: Raport Rzecznika Praw Obywatelskich z działalności w Polsce Krajowego Mechanizmu Prewencji w roku 2011, s. 45-46.

52 „Biuletyn RPO. Źródła” 2015, nr 4: Raport Rzecznika Praw Obywatelskich z działalności w Polsce Krajowego Mechanizmu Prewencji w roku 2014, s. 23-24. 
- Hinczewski przeciwko Polsce (skarga nr 34907/05), w związku z cenzurą korespondencji osób pozbawionych wolności;

- Przyjemski przeciwko Polsce (skarga nr 6820/07), w związku z cenzurą korespondencji osób pozbawionych wolności;

- Bereza przeciwko Polsce (skarga nr 42332/06), w związku z cenzurą korespondencji osób pozbawionych wolności;

- Nurzyński przeciwko Polsce (skarga nr 46859/06), w związku z odmową przyznania skarżącemu prawa do widzeń z rodziną podczas pobytu $\mathrm{w}$ areszcie;

- Knyter przeciwko Polsce (skarga nr 31820/06), w związku z odmową przyznania skarżącemu prawa do widzenia $\mathrm{z}$ rodziną $\mathrm{w}$ dniu 19 września 2006 r.;

- Krawczyk przeciwko Polsce (skarga nr 24205/06), w związku z restrykcjami stosowanymi podczas części widzeń z rodziną;

- Zieliński przeciwko Polsce (skarga nr 3390/05), w związku z cenzurą korespondencji.

\section{Pandemia COVID-19 a realizacja prawa skazanych do kontaktów ze światem zewnętrznym}

Omawiając zagadnienie realizacji prawa skazanych do kontaktów ze światem zewnętrznym, należy odnieść się także do sytuacji osadzonych, która zmieniła się w 2020 r. w następstwie pandemii COVID-19.

Skazani należą do osób najbardziej narażonych na zarażenie wirusem, ze względu na specyfikę warunków izolacji, które uznawane są za środowisko wysokiego ryzyka, gdyż jednostki penitencjarne nie są przystosowane do reagowania na zagrożenia epidemiologiczne na dużą skalę. Stosowanie podstawowych środków ochronnych, do których zalicza się dystans społeczny oraz określone zasad higieny, jest trudniejsze niż w warunkach wolnościowych. Okoliczności te wpływają na zwiększenie zagrożenia zdrowia więźniów ${ }^{53}$.

W celu zapobiegania szerzeniu się COVID-19 w miejscach detencji, kilka państw członkowskich zainicjowało zwolnienie niektórych kategorii więźniów. Wiele państw dostosowało swoją politykę w zakresie wymiaru sprawiedliwości w sprawach karnych tak, aby zmniejszyć liczbę więźniów przebywających w zakładach karnych. Dokonano tego za pomocą różnych środków, w tym tymczasowego lub przedterminowego zwolnienia

${ }^{53}$ COVID-19 pandemic: urgent steps are needed to protect the rights of prisoners in Europe. https://www.coe.int/en/web/commissioner/-/covid-19-pandemic-urgent-steps-areneeded-to-protect-the-rights-of-prisoners-in-europe [dostęp: 30.04.2021]. 
i amnestii, wprowadzono także areszt domowy oraz złagodzenie wyroków, a także zawieszanie dochodzeń i wykonywanie orzeczeń ${ }^{54}$.

W Polsce w marcu 2020 r., w związku z rozprzestrzenianiem się wirusa SARS-CoV-2, zostały ogłoszone nowe akty prawne, w tym Rozporządzenie Ministra Zdrowia z dnia 13 marca 2020 r. w sprawie ogłoszenia na obszarze Rzeczypospolitej Polskiej stanu zagrożenia epidemicznego (Dz.U. 2020 poz. 433), uchylone Rozporządzeniem Ministra Zdrowia z dnia 20 marca 2020 r. (Dz.U. 2020 poz. 491), stanowiącym akt jednorazowy, a także rozporządzenie Ministra Zdrowia z dnia 24 marca 2020 r. zmieniające rozporządzenie w sprawie ogłoszenia na obszarze Rzeczypospolitej Polskiej stanu epidemii (Dz.U. 2020 poz. 522), które umożliwiły zastosowanie radykalnych środków bezpieczeństwa mających na celu ochronę osadzonych oraz pracowników jednostek penitencjarnych przed zarażeniem.

Regulacje wynikające ze wskazanych aktów prawnych, a także zalecenia Państwowego Inspektora Sanitarnego stanowiły podstawę wprowadzenia określonych obostrzeń, mających wpływ na realizację prawa skazanych do kontaktów ze światem zewnętrznym. Wśród przedmiotowych obostrzeń wymienia się wstrzymanie udzielania osadzonym widzeń realizowanych na terenie jednostki penitencjarnej, wstrzymanie zatrudniania osadzonych poza obszarem jednostki oraz wstrzymanie odprawiania nabożeństw i udzielania posług religijnych. Ponadto wstrzymano udzielanie przepustek oraz wprowadzono specjalne procedury w przedmiocie organizacji kontaktów osadzonego z obrońcą na terenie jednostki penitencjarnej. Podkreślić należy, że każde potencjalne przedłużenie owych obostrzeń miało następować na podstawie regulacji zawartych w art. 247 $\S 2$ k.k.w..$^{55}$.

Szczególnie trudnym doświadczeniem dla osób pozbawionych wolności, związanym z powyższymi ograniczeniami, był brak kontaktu z osobami najbliższymi, w tym z dziećmi. W okresie od marca do lipca 2020 r. nie organizowano widzeń osadzonych z najbliższymi. W ślad za pismem Rzecznika Praw Obywatelskich do Służby Więziennej w sprawie wznowienia widzeń, wskazać należy, że 9 lipca 2020 r. Centralny Zarząd Służby Więziennej wydał komunikat, zgodnie z którym, nie póź-

54 Ibidem; COVID-19: what is happening in European prisons? European Prison Observatory, 2020. http://www.prisonobservatory.org/index.php?option=com_content $\&$ view=article \&id=32: covid-19-what-is-happening-in-european-prisons\&catid=7\&Itemid =101 [dostęp: 30.04 .2021 ].

${ }_{55}$ Zob. Zakład Karny w Krzywańcu, Dla interesantów, Widzenia. Służba Więzienna. https://www.sw.gov.pl/strona/dla-interesantow-zaklad-karny-w-krzywancu [dostęp: 2.02. 2020]; zob. Zakład Karny nr 1 we Wrocławiu, Dla interesantów, Widzenia, Komunikat - wstrzymanie widzeń. Służba Więzienna. https://www.sw.gov.pl/strona/dla-interesantowzaklad-karny-nr-1-we-wroclawiu [dostęp: 2.02.2020]. 
niej niż do dnia 1 sierpnia 2020 r., miało nastąpić przywrócenie widzeń osadzonych z najbliższymi. W późniejszym komunikacie, datowanym na 24 lipca 2020 r., przedstawiono zasady określające sposób odbywania się owych widzeń. Przyjęte ograniczenia wzbudziły wątpliwości nie tylko osadzonych, ale także Rzecznika Praw Obywatelskich, gdyż widzenia miały obejmować spotkanie z jedną osobą dorosłą należącą do najbliższych członków rodziny. W konsekwencji pominięto szeroki krąg osób, które mogły przed okresem pandemii utrzymywać stałe relacje z osadzonymi, m.in. w ramach widzeñ ${ }^{56}$.

Jak słusznie zauważa Rzecznik Praw Obywatelskich w piśmie do Służby Więziennej w sprawie widzeń z 29 lipca 2020 r.: „Bez względu na to, czy osadzony utrzymywał kontakt z najbliższą rodziną, czy też wyłącznie z innymi osobami bliskimi, ciężar psychiczny związany $\mathrm{z}$ brakiem bezpośredniego kontaktu jest porównywalny. Dlatego trudno znaleźć uzasadnienie dla dalszego pozbawienia części osadzonych możliwości utrzymywania kontaktu z osobami, które według nowo przyjętych zasad, nie należą do kręgu osób uprawnionych do realizacji widzeń" 57 .

W odpowiedzi Zastępcy Dyrektora Generalnego Służby Więziennej z 6 sierpnia 2020 r. na wspomniane pismo Rzecznika Praw Obywatelskich wskazano, że od 1 sierpnia 2020 r. wznowiono udzielanie widzeń osadzonym we wszystkich jednostkach penitencjarnych na terenie Polski. W indywidualnych przypadkach dopuszczono możliwość realizacji widzenia z osobami nie będącymi najbliższymi członkami rodziny osadzonego, jednakże decyzję $\mathrm{w}$ tym zakresie pozostawiono dyrektorom jednostek penitencjarnych. Nie dopuszczono udzielania widzeń z dziećmi, gdyż, jak wskazano, wizyty takie są nacechowane emocjami, wiek dzieci może uniemożliwić wytłumaczenie im

${ }^{56}$ Koronawirus. Wracaja widzenia osadzonych - ale tylko z jednym członkiem rodziny i bez dzieci. Interwencja Rzecznika. Rzecznik Praw Obywatelskich, 29.07.2020. https:// www.rpo.gov.pl/pl/content/wracaja-widzenia-osadzonych-z-rodzinami-ale-nie-z-dziecmiinterwencja-rpo [dostęp: 2.02.2020].

57 Pismo Zastępczyni Rzecznika Praw Obywatelskich Hanny Machińskiej do Zastępcy Dyrektora Generalnego Służby Więziennej płk. Andrzeja Leńczuka w sprawie widzeń z dnia 29 lipca 2020 r. Biuro Rzecznika Praw Obywatelskich. https://www.rpo.gov.pl/sites/default/ files/Pismo\%20do\%20S\%C5\%82u\%C5\%BCby\%20Wi\%C4\%99ziennej\%20ws. \%20 \%20wznowienia\%20widze\%C5\%84\%2C\%2029.07.2020.pdf [dostęp: 2.02.2020]; Odpowiedź Zastępcy Dyrektora Generalnej Służby Więziennej płk. Andrzeja Leńczuka, w sprawie widzeń z dziećmi, z dnia 6 sierpnia 2020 r., skierowana do Zastępczyni Rzecznika Praw Obywatelskich dr Hanny Machińskiej. Biuro Rzecznika Praw Obywatelskich. https://www.rpo.gov.pl/sites/default/files/Odpowied\%C5\%BA\%20DGSW\%20ws\%20 widze $\%$ C5\%84\%20z\%20dzie $\%$ C4\%87mi\%2C\%206.08.2020.pdf [dostęp: 2.02.2020]. 
konieczności zachowania dystansu czy też stosowania środków ochrony osobistej $^{58}$.

Wskazać zatem należy, że utrudnienie w realizacji prawa do kontaktów ze światem zewnętrznym wynikające $\mathrm{z}$ trwającej od początku $2020 \mathrm{r}$. pandemii COVID-19 stanowi przedmiot obserwacji zarówno funkcjonariuszy Służby Więziennej, jak i Rzecznika Praw Obywatelskich. Podejmowane są kolejne kroki w zakresie znoszenia obostrzeń, jednakże konieczne jest zachowanie środków ostrożności, gdyż jednostki penitencjarne, z uwagi na swoją specyfikę, są miejscem, w którym zapobieganie szerzeniu się COVID-19, tak jak innych chorób zakaźnych, może być bardzo trudne.

\section{Podsumowanie}

Podsumowując analizę podjętego zagadnienia, należy wskazać, że więzi, które osoby inkarcerowane nawiązują przed okresem pozbawienia wolności, odgrywają rolę w kształtowaniu się ich osobowości, poczucia przynależności do danej społeczności, a izolacja skazanych oznacza niejednokrotnie zerwanie tychże więzi, prowadzi do ograniczenia pewnych ról społecznych, wymusza zmianę zachowania, dostosowania się do nowych reguł, które skutkują ograniczoną możliwością decydowania o samym sobie.

Utrzymywanie kontaktów z bliskimi nie tylko stanowi element realizacji prawa do kontaktów ze światem zewnętrznym, ale także może zawierać się w indywidualnym programie oddziaływania ${ }^{59}$. Wiele okoliczności stanowi sposobność do umacniania więzi rodzinnych (dzień dziecka, dzień matki, dzień ojca, pikniki rodzinne, przedstawienia dla członków rodzin w ramach działalności artystycznej skazanych). Odpowiednie regulacje umożliwiają skazanym nie tylko utrzymywanie, ale także odnawianie więzi z członkami rodziny i innymi bliskimi ${ }^{60}$, przynosząc pozytywne wyniki resocjalizacyjne.

${ }^{58}$ Koronawirus. Więziennicy: widzenia osadzonych z dziećmi zbyt niebezpieczne. Rzecznik Praw Obywatelskich, 12.08.2020. https://www.rpo.gov.pl/pl/content/koronawiruswidzenia-osadzonych-z-dziecmi-zbyt-niebezpieczne-dgsw [dostęp: 2.02.2020].

${ }^{59}$ K. Lenart-KŁoś: Podmioty $i$ uwarunkowania resocjalizacji na przykładzie Aresztu Śledczego $w$ Lublinie. „Górnośląskie Studia Socjologiczne. Seria Nowa” 2013, nr 4, s. 195. http://bazhum.muzhp.pl/media//files/Gornoslaskie_Studia_Socjologiczne_Seria_ Nowa/Gornoslaskie_Studia_Socjologiczne_Seria_Nowa-r2013-t4/Gornoslaskie_Studia_ Socjologiczne_Seria_Nowa-r2013-t4-s185-203/Gornoslaskie_Studia_Socjologiczne_Seria_ Nowa-r2013-t4-s185-203.pdf [dostęp: 2.02.2020].

${ }^{60}$ Zob. art. 164 i 165 k.k.w. 
Pobyt $\mathrm{w}$ jednostce penitencjarnej będzie skutkował zaistnieniem wielu negatywnych dla izolowanej osoby zjawisk - stygmatyzacją, degradacją czy też depersonalizacją ${ }^{61}$. Jednakże $\mathrm{w}$ polskim systemie penitencjarnym podejmowanych jest wiele działań, które mają na celu niwelowanie wskazanych negatywnych skutków wykonywania kary pozbawienia wolności, m.in. w zakresie właściwej realizacji prawa skazanych do kontaktów ze światem zewnętrznym. Silna więź rodzinna winna być wykorzystywana do wspierania oraz wzmacniania procesu readaptacji społecznej, natomiast $\mathrm{w}$ przypadku osłabienia więzi należy podejmować kroki na rzecz jej wzmocnienia, m.in. poprzez zapewnienie skazanemu możliwie jak najczęstszych kontaktów z bliskimi. Celem podejmowanych działań resocjalizacyjnych jest m.in. pozytywna readaptacja społeczna skazanego, zwłaszcza w zakresie relacji z członkami rodziny czy też innymi osobami bliskimi, by po odbyciu kary pozbawienia wolności otrzymał on wsparcie i miał szansę na odbudowanie poczucia wartości oraz przynależności do społeczeństwa $^{62}$.

\section{Bibliografia}

\section{Literatura}

DĄBKIEWICz K.: Kodeks karny wykonawczy. Komentarz. Warszawa 2015.

DeKa R.: Readaptacja spoteczna skazanych jako jeden z warunków bezpieczeństwa społeczności lokalnych. W: Wielowymiarowość profilaktyki, resocjalizacji i readaptacji społecznej. Tradycja, wspótczesność i perspektywy inicjatyw probacyjnych. Red. P. FrącKowiak, M. SzYKut. Toruń 2017.

FRIEDRICH W.: Wychowawczo-resocjalizacyjne środki oddziatywania na skazanych. „Ogrody Nauk i Sztuk” 2016, t. 6.

LeLENTAL S.: Kodeks karny wykonawczy. Komentarz. Warszawa 2017.

LeLENTAL S.: Kodeks karny wykonawczy. Komentarz. Warszawa 2020 [Legalis].

Postulsкi K.: Kodeks karny wykonawczy. Komentarz. Warszawa 2017.

PotUlsкi J.: Rozdział X: Kara pozbawienia wolności. Nb. 1-4. W: Kodeks karny wykonawczy. Komentarz. Red. J. LachowsKi. Warszawa 2016.

SzcZYGIEe G.B.: Społeczna readaptacja skazanych $w$ polskim systemie penitencjarnym. Białystok 2002.

Szymanowski T.: Prawo karne wykonawcze z elementami polityki karnej $i$ penitencjarnej. Warszawa 2017.

Zgolí́ski I.: Rozdział X: Kara pozbawienia wolności. Nb. 8. W: Kodeks karny wykonawczy. Komentarz. Red. J. LachowsKi. Warszawa 2016.

${ }^{61}$ K. Linowski: Możliwości rozwoju człowieka..., s. 128.

${ }^{62}$ H. MACHEL: Rodzina skazanego..., s. 45-46. 


\section{Źródła internetowe}

Case of Polyakova and others v. Russia, Applications nos. 35090/09 and 3 others.European Court of Human Rights. https://hudoc.echr.coe.int/ eng\#\{“itemid":[“001-171774”]\} [dostęp: 30.04.2021].

COVID-19 pandemic: urgent steps are needed to protect the rights of prisoners in Europe. Council of Europe, 6.04.2020. https://www.coe.int/en/web/ commissioner/-/covid-19-pandemic-urgent-steps-are-needed-to-protect-therights-of-prisoners-in-europe [dostęp: 30.04.2021].

COVID-19: what is happening in European prisons? European Prison Observatory, 2020. http://www.prisonobservatory.org/index.php?option=com content \&view=article $\& i d=32$ : covid-19-what-is-happening-in-europeanprisons\&catid=7\&Itemid=101 [dostępu: 30.04.2021].

KIESzKowsKa A.: Problemy readaptacyjne osób opuszczajacych placówki resocjalizacyjne. „Probacja” 2009, nr 2. https://www.arch.ms.gov.pl/Data/Files/_public/ probacja/2009/nr2/7kieszkowska.pdf [dostęp: 30.04.2021].

Komentarz do Europejskich Reguł Więziennych. Council of Europe. https://search. coe.int/cm/Pages/result_details.aspxObjectId=09000016809c9086][dostęp: 23.04.2021].

Koronawirus. Więziennicy: widzenia osadzonych z dziećmi zbyt niebezpieczne. Rzecznik Praw Obywatelskich, 12.08.2020. https://www.rpo.gov.pl/pl/ content/koronawirus-widzenia-osadzonych-z-dziecmi-zbyt-niebezpiecznedgsw [dostęp: 2.02.2021].

Koronawirus. Wracaja widzenia osadzonych - ale tylko z jednym członkiem rodziny i bez dzieci. Interwencja Rzecznika. Rzecznik Praw Obywatelskich, 29.07.2020. https://www.rpo.gov.pl/pl/content/wracaja-widzenia-osadzonych-z-rodzinami-ale-nie-z-dziecmi-interwencja-rpo [dostęp: 2.02.2021].

Lenart-KŁoś K.: Podmioty $i$ uwarunkowania resocjalizacji na przykładzie Aresztu Śledczego w Lublinie. „Górnośląskie Studia Socjologiczne. Seria Nowa” 2013, t.4.http://bazhum.muzhp.pl/media//files/Gornoslaskie_Studia_Socjologiczne_ Seria_Nowa/Gornoslaskie_Studia_Socjologiczne_Seria_Nowa-r2013-t4/ Gornoslaskie_Studia_Socjologiczne_Seria_Nowa-r2013-t4-s185-203/ Gornoslaskie_Studia_Socjologiczne_Seria_Nowa-r2013-t4-s185-203.pdf [dostęp: 2.02.2021].

LINOWsKI K.: Możliwości rozwoju człowieka w warunkach izolacji penitencjarnej poprzez utrzymywanie kontaktów zewnętrznych. „Acta Scientifica Academiae Ostroviensis" 2011, nr 8. http://bazhum.muzhp.pl/media//files/Acta_ Scientifica_Academiae_Ostroviensis/Acta_Scientifica_Academiae_Ostroviensisr2001-t-n8/Acta_Scientifica_Academiae_Ostroviensis-r2001-t-n8-s125-143/ Acta_Scientifica_Academiae_Ostroviensis-r2001-t-n8-s125-143.pdf [dostęp: 2.02.2021].

MACHEL H.: Rodzina skazanego jako współuczestnik jego resocjalizacji penitencjarnej, readaptacji $i$ reintegracji społecznej. „Resocjalizacja Polska” 2014, nr 7, http://bazhum.muzhp.pl/media//files/Resocjalizacja_Polska_ (Polish_Journal_of_Social_Rehabilitation)/Resocjalizacja_Polska_(Polish_ Journal_of_Social_Rehabilitation)-r2014-t7/Resocjalizacja_Polska_(Polish_ 
Journal_of_Social_Rehabilitation)-r2014-t7-s45-57/Resocjalizacja_Polska_ (Polish_Journal_of_Social_Rehabilitation)-r2014-t7-s45-57.pdf [dostęp: 2.02. 2021].

Odpowiedź Zastępcy Dyrektora Generalnej Służby Więziennej płk. Andrzeja Leńczuka w sprawie widzeń z dziećmi, z dnia 6 sierpnia 2020 r., skierowana do Zastępczyni Rzecznika Praw Obywatelskich dr Hanny Machińskiej. Biuro Rzecznika Praw Obywatelskich. https://www.rpo.gov.pl/sites/default/ files/Odpowied\%C5\%BA\%20DGSW\%20ws\%20widze\%C5\%84\%20z\%20 dzie\%C4\%87mi\%2C\%206.08.2020.pdf [dostęp: 2.02.2021].

Pismo Zastępczyni Rzecznika Praw Obywatelskich Hanny Machińskiej do Zastępcy Dyrektora Generalnego Służby Więziennej płk. Andrzeja Leńczuka w sprawie widzeń z dnia 29 lipca 2020 r. Biuro Rzecznika Praw Obywatelskich. https://www.rpo.gov.pl/sites/default/files/Pismo\%20do\%20S\%C5\% 82u\%C5\%BCby\%20Wi\%C4\%99ziennej\%20ws.\%20\%20wznowienia\%20 widze\%C5\%84\%2C\%2029.07.2020.pdf [dostęp: 2.02.2021].

Zakład Karny nr 1 we Wrocławiu, Dla interesantów, Widzenia, Komunikat wstrzymanie widzeń. Służba Więzienna. https://www.sw.gov.pl/strona/dlainteresantow-zaklad-karny-nr-1-we-wroclawiu [dostęp: 2.02.2021].

Zakład Karny w Krzywańcu, Dla interesantów, Widzenia. Służba Więzienna. https://www.sw.gov.pl/strona/dla-interesantow-zaklad-karny-w-krzywancu [dostęp: 2.02.2021].

\section{Raporty}

„Biuletyn RPO. Źródła” 2012, nr 5: Raport Rzecznika Praw Obywatelskich z dziatalności w Polsce Krajowego Mechanizmu Prewencji w roku 2011.

„Biuletyn RPO. Źródła” 2015, nr 4: Raport Rzecznika Praw Obywatelskich z dziatalności w Polsce Krajowego Mechanizmu Prewencji w roku 2014.

„Biuletyn RPO. Źródła” 2016, nr 4: Raport Rzecznika Praw Obywatelskich z dziatalności w Polsce Krajowego Mechanizmu Prewencji w roku 2015.

„Biuletyn RPO. Źródła” 2017, nr 4: Raport Rzecznika Praw Obywatelskich z dziatalności w Polsce Krajowego Mechanizmu Prewencji Tortur w roku 2016.

„Biuletyn RPO. Źródła” 2019: Raport Rzecznika Praw Obywatelskich z działalności $w$ Polsce Krajowego Mechanizmu Prewencji Tortur w roku 2018.

„Biuletyn RPO. Źródła” 2020, nr 3: Raport Rzecznika Praw Obywatelskich z dziatalności w Polsce Krajowego Mechanizmu Prewencji Tortur w roku 2019.

\section{Akty prawne}

Ustawa z dnia 6 czerwca 1997 r. Kodeks karny wykonawczy. Dz.U. 1997 nr 90 poz. 557 z późn. zm.

Ustawa z dnia 6 czerwca 1997 r. Kodeks karny. Dz.U. 1997 nr 88 poz. 553 z poźn. $\mathrm{zm}$.

Europejska Konwencja Praw Człowieka. Council of Europe. https://www.echr. coe.int/Documents/Convention_POL.pdf [dostęp: 30.04.2021].

Konwencja o Ochronie Praw Człowieka i Podstawowych Wolności sporządzona w Rzymie dnia 4 listopada 1950 r., zmieniona następnie Protokołami nr 3, 5 i 8 oraz uzupełniona Protokołem nr 2. Dz.U. 1993 nr 61 poz. 284. 
Międzynarodowy Pakt Praw Obywatelskich i Politycznych otwarty do podpisu w Nowym Jorku dnia 19 grudnia 1966 r. Dz.U. 1977 nr 38 poz. 167.

Rekomendacja Rec (2006) 2 Komitetu Ministrów do państw członkowskich Rady Europy w sprawie Europejskich Reguł Więziennych. http://www.bip. sw.gov.pl/SiteCollectionDocuments/CZSW/prawaczl/document.pdf [dostęp: 2.02.2020].

Rozporządzenie Ministra Sprawiedliwości z dnia 21 grudnia 2016 r. w sprawie regulaminu organizacyjno-porządkowego wykonywania kary pozbawienia wolności. Dz.U. 2016 poz. 2231.

Rozporządzenie Ministra Zdrowia z dnia 13 marca 2020 r. w sprawie ogłoszenia na obszarze Rzeczypospolitej Polskiej stanu zagrożenia epidemicznego. Dz.U. 2020 poz. 433.

Rozporządzenie Ministra Zdrowia z dnia 20 marca 2020 r. w sprawie ogłoszenia na obszarze Rzeczypospolitej Polskiej stanu epidemii. Dz.U. 2020 poz. 491.

Rozporządzenie Ministra Zdrowia z dnia 24 marca 2020 r. w sprawie ogłoszenia na obszarze Rzeczypospolitej Polskiej stanu zagrożenia epidemii. Dz.U. 2020 poz. 522. 